\title{
Laboratory Evaluation of Some Essential Oils against Immature Stages of The Filarial Mosquito Culex quinquefasciatus (Diptera:Culicidae)
}

\author{
Abir A. Gad ${ }^{1}$
}

\begin{abstract}
The larvicidal activity of four commercially available essential oils were tested on the $4^{\text {th }}$ larval instar of Culex quinquefasciatus in the laboratory. These were the essential oils of Cinnamomum osmophloeum (cinnamon), Matricharia chamomella (chamomell), Nigella sativa(nigela) and Sesamum indicum (sesame) oils. The toxicity index, $\mathrm{LC}_{50}$ values, $\mathrm{LC}_{50}$ values were $26,32,82$ and $26 \mathrm{ppm}$ for cinnamon, chamomell, nigela and sesame oils, respectively after 48 hrs from treatment. All tested oils, at high concentrations, had high larvicidal toxicity. Furthermore, the increase of concentrations was directly proportional to reduction in pupation rates and adult emergence. Significant decrease in pupation rate was observed by cinnamon oil at 65 ppm. Adult emergence was $100 \%$ inhibited in cinnamon oil was used, especially at concentrations 50 and 6 were 5 ppm. The number of eggs/ female and eggs hatchability were also decreased by the application of all concentration of the tested oils. In addition, the tested plant oils exhibited various morphological abnormalities on larvae, pupae and adult stages The result from this study demonstrated that essential oil of cinnamon was the most potent oil and was the major cause of malformation of both larval and pupal stages.
\end{abstract}

Keywords: Culex quinquefasciatus, Cinnamomum osmophloeum, Matricharia chamomella, Nigella sativa, Sesamum indicum, larvicidal activity, Morphological abnormalities, essential oils.

\section{INTRODUCTION}

Mosquito is the principal vector of many of diseases affecting human beings and other vertebrates. (El Hag et al., 1999). The mosquito, Culex quinquefasciatus Say (Family: Culicidae), is the potential vector of bancroftian filariasis through the world. The high $C x$ .quinquefasciatus population density in the cosmotropical area has triggered several interventions by the public health authorities using wide synthetic insecticide as the main of combat and control. The conventional organophosphate, carbamate and pyrethroides insecticides that are generally used for mosquito control, are known to cause the problem of environmental pollution, residual effects and resistance by their indiscriminate use (Brown, 1986). This dictates the need to develop environmentally safe, effective and preferably locally available control agents for mosquito control. Plants are rich source of bioactive organic chemicals and offer an advantage over synthetic pesticides as these are less toxic, less prone to the development of resistance (World Health Organization, 1981) and easily biodegradable (Forget, 1989). The mosquito control at the larval stage of development with phytochemicals that occur in the oils, leaves ,roots and bark of plants is one of the techniques which affords a cheap, easy to use, and environment friendly method of filarial control. Studies have shown the potential of plants for use in $C x$. quinquefasciatus larvae control ; Azadirachta indica (Sharma et al. 2009) Melia azedarach L. (Family: Meliaceae) (Al-Mehmadi and AlKhalaf 2010), and the leaf essential oil of Matricharia chamomella (Family: Asteraceae) (El-Dakhil 2011). The Meliaceae plant family has been known as a potential source for insecticide properties. Cinnamon extracts are favored for their nice odour and their environmentally friendly pesticides, (Chang et al., 2001). They had excellent antibacterial, antitermite, antipathogenic, antifungal and anti-inflammatory activities (Chang et al., 2001; Chang and Cheng, 2002; Chao, et al., 2005; Lee, et al., 2005; Cheng et al., 2006 and Chao, et al., 2008).

Extracts from the Cinnamon bark and leaves of have shown targeting excellent insecticidal properties fecundity and fertility of mosquito species and were at the same time very eco-friendly (Cheng et al., 2004).

Ethanolic extracts of Artemisia herba alba, Matricharia chamomella and Melia azedarach are effective oviposition deterrent and skin repellent against Culex quinquefasciatus ( Al-Mehmadi and Al- Khalaf. 2010).

The present study is aimed to determine the effects of four essential oils on the $4^{\text {th }}$ instar larvae of $C x$. quinquefasciatus.

\section{MATERIALS AND METHODS}

\section{Mosquito strain rearing}

A laboratory-sensitive strain of $C x$. quinquefasciatus colony was obtained at the larval stage from the laboratory in the College of Food and Agricultural Science, King Saud University in Riyadh. Mosquito were held at $27 \pm 1^{\circ} \mathrm{C}$ and $70 \pm 5 \% \mathrm{RH}$, and a photo regime of 14: $10 \mathrm{hr}$ (L:D) photoperiod until pupation. Adults were provided a $10 \%$ sucrose solution as a food

\footnotetext{
${ }^{1}$ Department of Applied Entomology, Faculty of Agriculture, Alexandria University, Egypt

Received November 8, 2012, Accepted February17, 2013
} 
source. A pigeon was introduced twice a week to adults for a blood meal. Larvae were reared in dechlorinated water under the same conditions and were fed daily with baby fish food.

\section{Plant extracts used}

Four plant extracts namely, Cinnamomum osmophloeum (cinnamon), Matricharia chamomella (chamomell), Nigella sativa (nigela) and Sesamum indicum (sesame), were tested against $4^{\text {th }}$ instar larvae of $C x$. quinquefasciatus mosquitoes. The plant extracts were obtained from Anada Apothecary Company (Germany).They were stored in dark glass bottles at low temperature $\left(4^{\circ} \mathrm{C}\right)$ until use.

\section{Larvicidal assay}

Larvicidal activity against $C x$. quinquefasciatus was assayed using the World Health Organization (WHO) standard method (WHO, 1981). For the assays, $1 \mathrm{ml}$ of each essential oil was dissolved in $100 \mathrm{ml}$ distilled water + One drop of the emulsifier triton $\mathrm{x}-100$, (Sigma Chemical Company, UK) to insure complete solubility of the material in water. Series of concentrations ranging from 10 to 600 ppms of dissolved oil were prepared. Three replicates were used for each concentration. Twenty larvae were distributed in each replicate (glass beaker), containing $100 \mathrm{ml}$ of water. Larvae maintained in distilled water + one drop of triton $\mathrm{x}-100$, were used as a control. Mortality counts were carried out after $24 \mathrm{hr}$ of treatment and until pupation. Larval mortality counts were calculated and corrected according to Abbott, (1925).

The median lethal concentration $\left(\mathrm{LC}_{50}\right)$ values of the four tested essential oils were calculated using probit analysis as described by Finney, (1971).

The effects of the four essential oils on some biological aspects such as, the developmental periods, the number of developed pupae, the number of adult emergence and the adult mortality were also recorded.

\section{Data analysis:}

Data were statistically analyzed to check the significance of differences between treatments by using F test and L.S.D. (Steel and Torrie, 1980).

\section{RESULTS}

All the tested oils were effective against the $4^{\text {th }}$ larval instar of $C x$. quinquefasciatus. The calculated $\mathrm{LC}_{50}$ values were $26,32,82$ and $26 \mathrm{ppm}$ for cinnamon, chamomell, nigela and sesame oils, respectively. Such values indicated that cinnamon was the most effective oil, whereas Sesame oil was the least effective one.

As a consequence of larval treatments, some biological features were conspicuously varied, such as, the developmental periods, the pupation rates, adult emergences. The developmental periods of larvae and pupae were prolonged at all concentrations of cinnamon oil but they produced no significant difference in the larvae. The pupae showed significantly different changes of durations from that of the control groups except at 35, $50 \mathrm{ppm}$. (Fig.,1a\&b) Beyond, this point, the higher the concentration, the greater the effect of oils on larval developmental periods. Sesame oil concentrations tend to shorten the duration of larvae when compared with that of the control group.(Fig., 2a,b). The developmental periods of larval and pupal stage were prolonged after treatment with the lowest concentrations of chamomell and nigela oil.(Fig., 3a,b and $4 a, b)$. The longest larval periods were 10.75 and 8.56 days, respectively after treatment larvae with 10 ppm of chamomell oil, 100 ppm of cinnamon oil and 10 ppm of nigela oil. For all the tested oils the pupation rates and the adult emergences decreased as the concentration increased. Adult emergences were completely stopped by the concentrations of cinnamon oil from 50 to $100 \mathrm{ppm}$ (Tables, 1).

The delayed effects of the tested essential oils on the reproductive potential of $C x$. quinquefasciatus mosquito adults that emerged from larval treatments during $1^{\text {st }}$ gonotrophic cycle of mosquito females were recorded. There was a significant decrease in the number of eggs laid by the mosquito females that developed from surviving larvae after treatment with sesame, chamomell and nigela oils compared with the control groups. The lowest number of eggs / female were 166, 215 and 168 eggs/female, respectively after treatment larvae with 60 ppm of sesame, $45 \mathrm{ppm}$ of chamomell and $40 \mathrm{ppm}$ of nigela oils compared with control group .(Table, $2 \& 3 \& 4)$. On the other hand, nigela oil at concentrations 45, 50 and $60 \mathrm{ppm}$, the females did not lay eggs.

The present results were agreement with the study of Ahmed, (2007), who found that feeding the adults of Anopheles gambiae on the mixture of $3 \%$ black seed oil and $10 \%$ glucose solution caused a significant reduction in the total number of fully developed oocysts.

The number of hatched eggs were markedly decrease in all tested oils concentrations, the percentage of inhibition were $61.8,90$ and $65.1 \%$, respectively after treating larvae with $45 \mathrm{ppm}$ of chamomell oil, $40 \mathrm{ppm}$ of neglia oil and $40 \mathrm{ppm}$ of sesame oil, when compared with the control groups.

The negative effects of these essential oils on the fecundity and hatchability of eggs of $C x$. quinquefasciatus mosquitoes may be due to two factors that may cause such a reduction in the reproductive potential of mosquitoes. 
Table 1. The biological effect of Cinamon oil on Culex quinquefasciatus

Cinommn oil (ppm)

\begin{tabular}{c}
\hline 25 \\
\hline 35 \\
\hline 50 \\
\hline 65 \\
\hline 75 \\
\hline 85 \\
\hline 100 \\
\hline
\end{tabular}

Control

\section{Pupation}

$(\% \pm \mathrm{SE})$

\begin{tabular}{l}
$44 \pm 0.35^{\mathrm{b}}$ \\
$29 \pm 0.41^{\mathrm{c}}$ \\
\hline $27 \pm 0.32^{\mathrm{c}}$ \\
\hline $10 \pm 0.23^{\mathrm{d}}$ \\
\hline $0.0 \pm 0.0^{\mathrm{e}}$ \\
$0.0 \pm 0.0^{\mathrm{e}}$ \\
\hline $0.0 \pm 0.0^{\mathrm{e}}$ \\
$\mathbf{9 6} \pm \mathbf{0 . 3} \mathbf{3}^{\mathrm{a}}$
\end{tabular}

Emergence

$(\% \pm \mathrm{SE})$

\begin{tabular}{l}
$6.0 \pm 0.1^{\mathrm{b}}$ \\
\hline $5.0 \pm 0.1^{\mathrm{b}}$ \\
$0.0 \pm 0.0^{\mathrm{c}}$ \\
$0.0 \pm 0.0^{\mathrm{c}}$ \\
\hline $0.0 \pm 0.0^{\mathrm{c}}$ \\
$0.0 \pm 0.0^{\mathrm{c}}$ \\
\hline $0.0 \pm 0.0^{\mathrm{c}}$ \\
$\mathbf{9 8} \pm 0.1^{\mathrm{a}}$
\end{tabular}

Number of deposited eggs/female
Number of hatched eggs

Table2.The biological effect of Sesame oil on Culex quinquefasciatus

\begin{tabular}{|c|c|c|c|c|}
\hline $\begin{array}{l}\text { Sesame oil } \\
(\mathbf{p p m})\end{array}$ & $\begin{array}{l}\text { Pupation } \\
(\% \pm \text { SE })\end{array}$ & $\begin{array}{l}\text { Emergence } \\
(\% \pm \mathrm{SE})\end{array}$ & $\begin{array}{c}\text { Number of } \\
\text { deposited } \\
\text { eggs/female }\end{array}$ & $\begin{array}{c}\text { Number of } \\
\text { hatched eggs }\end{array}$ \\
\hline 10 & $59 \pm 0.4^{b}$ & $38 \pm 0.4^{b}$ & $545 \pm 1.2^{\mathrm{a}}$ & $338 \pm 9.6^{b}$ \\
\hline 20 & $51 \pm 0.5^{b}$ & $33.1 \pm 0.3^{b}$ & $312 \pm 1.7^{b}$ & $145 \pm 8.1^{c}$ \\
\hline 30 & $50 \pm 0.4^{b}$ & $32.1 \pm 0.3^{b}$ & $296 \pm 1.5^{b}$ & $105 \pm 7.7^{\mathrm{c}}$ \\
\hline 40 & $41 \pm 0.1^{b}$ & $29.3 \pm 0.5^{b}$ & $218 \pm 1.5^{b}$ & $76 \pm 5.2^{d}$ \\
\hline 50 & $37 \pm 0.3^{c}$ & $28.6 \pm 0.6^{b}$ & $177 \pm 1.3^{c}$ & -- \\
\hline 60 & $24 \pm 0.2^{c}$ & $12.3 \pm 0.3^{c}$ & $168 \pm 1.2^{c}$ & -- \\
\hline Control & $94 \pm 1.3^{a}$ & $95 \pm 0.9^{a}$ & $658 \pm 1.3^{a}$ & $493 \pm 9.2^{a}$ \\
\hline \multicolumn{5}{|c|}{ Table 3.The biological effect of Chamomell oil on Culex quinquefasciatus } \\
\hline $\begin{array}{c}\text { Chamomell oil } \\
\text { (ppm) }\end{array}$ & $\begin{array}{c}\text { Pupation } \\
(\% \pm \text { SE })\end{array}$ & $\begin{array}{c}\text { Emergence } \\
(\% \pm \mathrm{SE})\end{array}$ & $\begin{array}{c}\text { Number of } \\
\text { deposited } \\
\text { eggs/female }\end{array}$ & $\begin{array}{c}\text { Number of } \\
\text { hatched eggs }\end{array}$ \\
\hline 10 & $83 \pm 0.67^{\mathrm{a}}$ & $92.5 \pm 1.3^{\mathrm{a}}$ & $421 \pm 0.3^{a}$ & $56.5 \pm 1.6^{b}$ \\
\hline 25 & $78 \pm 0.62^{\mathrm{ab}}$ & $92 \pm 0.8^{\mathrm{a}}$ & $363 \pm 0.5^{\mathrm{ab}}$ & $42.2 \pm 1.3^{b}$ \\
\hline 30 & $62 \pm 0.60^{\mathrm{b}}$ & $85.5 \pm 1.0^{\mathrm{a}}$ & $327 \pm 0.6^{b}$ & $38 \pm 1.3^{b}$ \\
\hline 35 & $54 \pm 0.45^{b}$ & $78.2 \pm 0.9^{\mathrm{ab}}$ & $301 \pm 0.7^{b}$ & $31.2 \pm 1.2^{b}$ \\
\hline 40 & $31 \pm 0.62^{c}$ & $74 \pm 0.7^{b}$ & $238 \pm 0.4^{\mathrm{bc}}$ & $25.4 \pm 1.1^{\mathrm{c}}$ \\
\hline 45 & $25 \pm 0.43^{c}$ & $71.2 \pm 0.7^{b}$ & $166 \pm 0.5^{\mathrm{c}}$ & $59.03 \pm 1.4^{b}$ \\
\hline 50 & $13 \pm 0.22^{\mathrm{e}}$ & $41.7 \pm 0.4^{\mathrm{c}}$ & $142 \pm 0.5^{\mathrm{c}}$ & $61.8 \pm 1.2^{b}$ \\
\hline Control & $91 \pm 1.63^{a}$ & $100 \pm 1.3^{a}$ & $456 \pm 0.7^{a}$ & $312 \pm 0.8^{a}$ \\
\hline
\end{tabular}

Table 4. The biological effect of Neglia oil on Culex quinquefasciatus

Neglia oil

(ppm)

\section{Pupation}

(\% $\%$ SE)

\begin{tabular}{cc}
\hline 10 & $39 \pm 0.1^{\mathrm{b}}$ \\
\hline 25 & $37 \pm 0.2^{\mathrm{b}}$ \\
\hline 30 & $31 \pm 0.2^{\mathrm{b}}$ \\
\hline 35 & $30.7 \pm 0.4^{\mathrm{b}}$ \\
\hline 40 & $26.1 \pm 0.3^{\mathrm{b}}$ \\
\hline 45 & $21.2 \pm 0.3^{\mathrm{c}}$ \\
\hline 50 & $17 \pm 0.1^{\mathrm{c}}$ \\
\hline 60 & $9.2 \pm 0.5^{\mathrm{d}}$ \\
\hline
\end{tabular}

Control

$92 \pm 0.5^{\mathrm{a}}$

\section{Emergence}

$(\% \pm \mathrm{SE})$

\begin{tabular}{c}
$28.1 \pm 0.4^{\mathrm{b}}$ \\
\hline $26.3 \pm 0.6^{\mathrm{b}}$ \\
\hline $27 \pm 0.5^{\mathrm{b}}$ \\
$25.3 \pm 0.3^{\mathrm{b}}$ \\
\hline $23.5 \pm 0.1^{\mathrm{b}}$ \\
$16.6 \pm 0.1^{\mathrm{b}}$ \\
$18.2 \pm 0.5^{\mathrm{b}}$ \\
$14.1 \pm 0.4^{\mathrm{c}}$ \\
$\mathbf{9 0 \pm 0 . 7 ^ { \mathrm { a } }}$
\end{tabular}

Number of deposited eggs/female

$\begin{array}{cc}563 \pm 0.6^{\mathrm{b}} & 169 \pm 6.3^{\mathrm{b}} \\ 506 \pm 0.5^{\mathrm{b}} & 139 \pm 7.1^{\mathrm{b}} \\ 478 \pm 0.7^{\mathrm{c}} & 75 \pm 5.2^{\mathrm{c}} \\ 318 \pm 0.5^{\mathrm{c}} & 46 \pm 3.1^{\mathrm{c}} \\ 215 \pm 0.3^{\mathrm{d}} & 43 \pm 3.3^{\mathrm{c}} \\ -- & -- \\ -- & -- \\ -- & -- \\ \mathbf{8 5 2} \pm 7^{\mathbf{a}} & \mathbf{5 8 9} \pm \mathbf{6 . 3} \\ \end{array}$




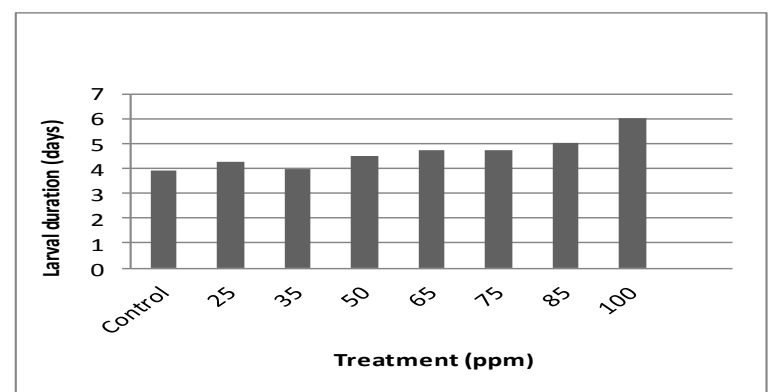

Fig. 1a. Effect of Cinnamon oil on $C x$. quinquefasciatus larval duration.

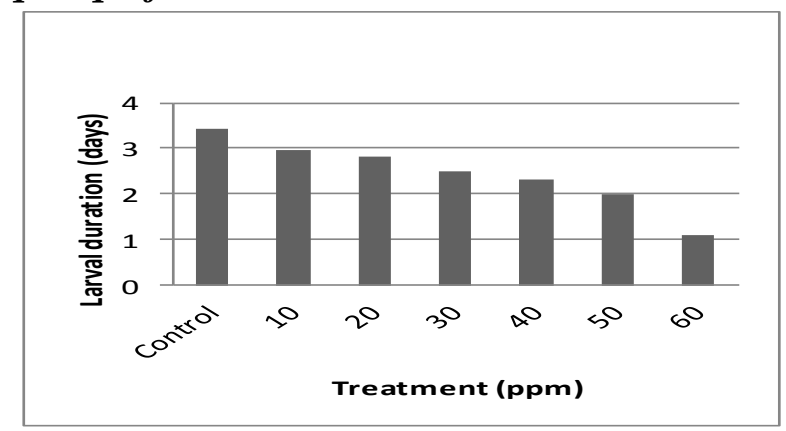

Fig. 2a. Effect of Seasam oil on $C x$. quinquefasciatus larval duration.

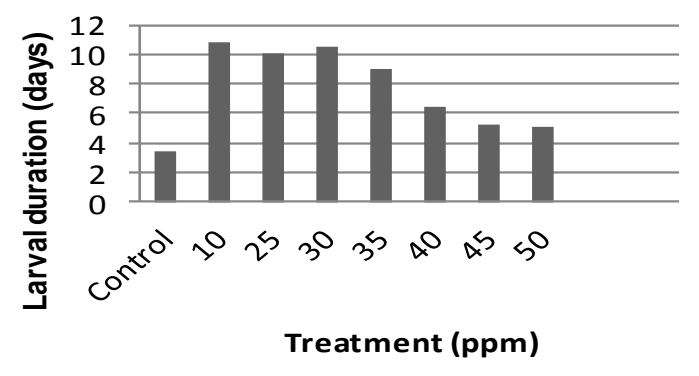

Fig. 3a. Effect of Chamomell oil on $C x$. quinquefasciatus larval duration.

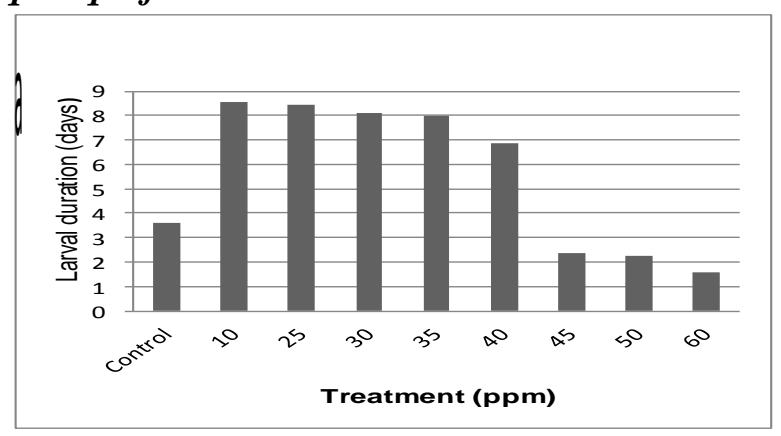

Fig. 4a. Effect of Negila oil on $C x$. quinquefasciatus larval duration.

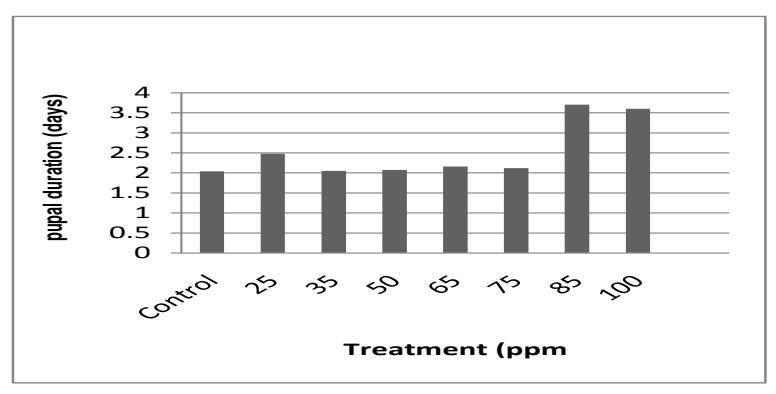

Fig. 1b. Effect of Cinnamon oil on $C x$. quinquefasciatus pupal duration.

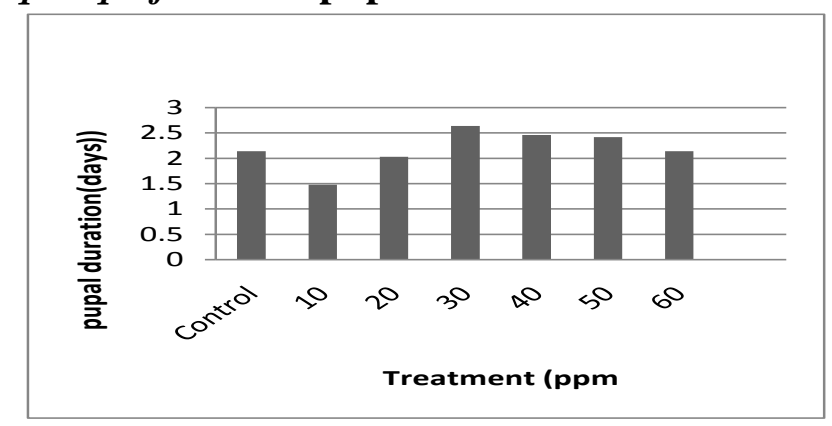

Fig., 2b. Effect of Seasam oil on $C x$. quinquefasciatus pupal duration.

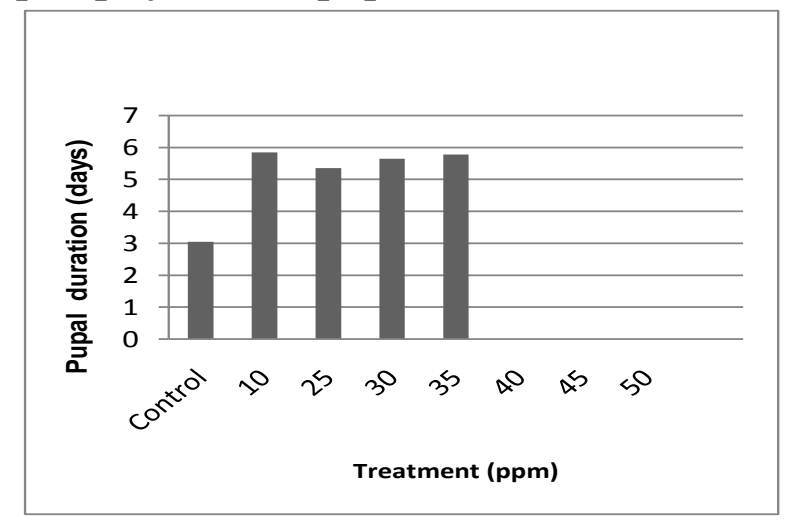

Fig. 3b. Effect of Chamomell oil on $C x$. quinquefasciatus pupal duration.

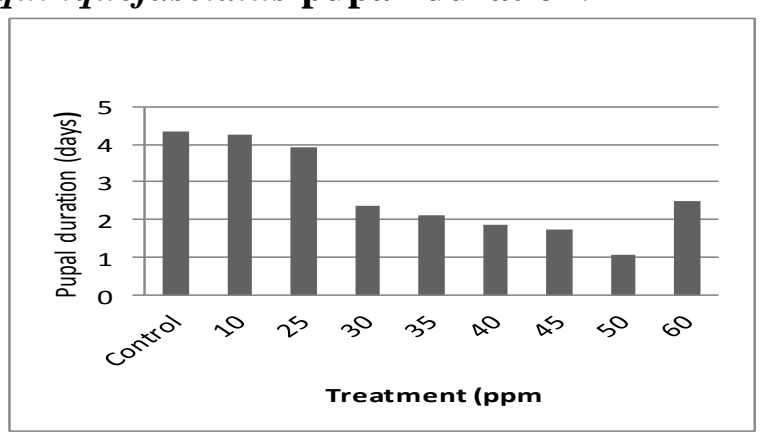

Fig. 4b. Effect of Negila oil on $C x$. quinquefasciatus pupal duration. 
First, the exposure of mosquito larvae continuously to sub-lethal doses of bioinsecticide that affect the gonads and accordingly the reproductive capacity of adult survivors. Second, some engorged females, that survived these treatments, ultimately oviposite very few eggs, most of which fail to hatch successfully (Muthukrishnan and Puspalatha, 2001).

Several forms of morphological malformations resulted from treatment of larvae with the applied oils. The abnormal larval were pigmented and twisted, as well as larval-pupal intermediates (pharate pupae). Whereas, the deformed pupa were albino pupae with blackish cephalothorax. The adults aberrations was failure in eclosion, and deformed abdomen and legs.

These result agree with the result of several studies for using other plant extract against mosquito species. Chaithong et al.,(2006), demonstrated that treatment of Aedes larvae with pepper extract caused damage and shrunken cuticle of anal papillae. Further studies conducted by Insun et al., (1999) revealed that several morphological disruption of anal papillae observed in dead $C x$. quinquefasciatus larvae after treatment of Kaempferia galanga extract.

\section{DISCUSSIONS}

In the light of the emergence of mosquito vectors diseases showing resistance to conventional chemical pesticides, several authors reported earlier the potential larvicidal activities of different plant species against mosquitoes like Anopheles stephensiliston as well as $C x$. quinquefasciatus (Family: Culicidae).

The longevity of the larvae was prolonged maximally in the case of treatment with Niglla sativa . Almost the same maximum prolonged duration was achieved when the larvae were treated with Matricharia chamomilla. The number of pupae resulting from the treated larvae was less than those of these control, although the duration of the pupal stage was not much different for both groups (treated and control).

The prolongation of the tested $3^{\text {th }}$ larval period might be due in part to the effects of the these plant extracts on the tissues of insects. Khalaf, (1998), Shoukry and Hussein, (1998) and Abou El-Ela et al. (1995) reported that the total carbohydrates, proteins and lipids decreased in the last instar larvae of Galleria mellonella when treating third larval instar with some plant volatile oils.

Moreover, no adults emerged when the larvae were treated with Cinnamomum osmophloeum because all the larvae and pupae died before developing into the adult stage. The present result found that the total period of development of the mosquito Cx. quinquefasciatus may have been affected because the larval duration was prolonged compared with the control group. These results correspond with those reached by Khalaf et al. (2010) who found that when the larvae of mosquito Culex quinquefasciatus were treated with $\mathrm{LC}_{50}$ concentration of plant extract of Mela azedarach, none succeed to emerge in the adult stage.

Jayaprakasha et al. ( 1997) studied the larvicidal activity of the isolated main ingredient, lemonine, from the citrus reticulate Blan (Family : Rutaceae) sesame, Sesamum indicum, nigela, Nigella sativa, and onion, Allium cepa, oils were highly toxic to Culex pipiens. Khater (2003) reported that essential oil and cinnamaldhyde from leaves of Cinnamomum osmophloeum exhibited the strongest mosquito larvicidal activity against fourth instar Aedes aegypti larvae as well as against $C x$. quinquefasciatus and Armigeres sublbatus larvae.

Moreover, Al-Mehmadi and Al-Khalaf (2010). suggested that the ethanol extracts of Artemisia herba alba, Matricharia chamomella and Mela azedarach are effective ovipostion deterrent and skin repellent against $C x$. quinquefasciatus. In the present investigation, the cinnamon and chamomell oils showed excellent larvicidal activity against $C x$. quinquefasciatus, and this was the first report on biocontrol of $C x$. quinquefasciatus mosquito using cinnamon and sesame oils. The low percentage of pupation that preceded larvaes failure to develop to this stage may be explained either by the effective impact of the components of the botanical extracts, which are considered pathological agents spreading in the digestive system of the larvae, cause of physiological impediment processes interfering with the process of transformation to the pupal stage (Kalaf et al. 2010).

Regarding the morphological abnormalities, several authors recorded similar anomalies, when applied different plant extracts at sub-lethal concentrations. Pigmented larvae and pharate pupae were reported after treatment with plant extract (Khater, 2003). Albino pupae were recorded after treatment with neem seed kernel extract (Desoky, 1995) and nigela oil (Khater, 2003). Last abdominal segment of $C x$. quinquefasciatus, larvae which ended in two pairs of transparent papillae showed abnormal pigmentation with elongation, were observed after treatment with cinnamon oil (El- Dakhil, 2011).

Finally, failure of adult eclosion as well as deformed abdomen and legs were recorded after treatment with sesame, nigela and onion oils and garlic oil (Saleh, 1995). 
These results indicated a metamorphosis inhibiting effect of the plant oils, which possibly based on the disturbance of hormonal control (Al -Sharook et al. (1991). The most important deformities, larval-pupal intermediates and ecdysal failure, seemed to be the major cause of the mortalities. With reference to biological aspects, the data revealed prolongation of the larval developmental periods. Following treatment with concentrations of chamomell, nigela and sesame oils $10.75,8.41$ and 9.26 days, respectively. Similar results were recorded after treatment of $c$. pipiens with onion, sesame, and nigela oils 12.6, 9.3 and 8.5 days, respectively (Khater, 2003).

The prolongation of developmental periods occurred because plant extract had insect growth regulation activity, which may inhibit insect development (Mohsen, 1990 and Sivagnaname and Kalyanasundaram 2004).

The present results show a reduction in pupation rates and adult emergences, following exposure to higher concentrations of several plant extracts. Simillar observations were reported by many authors after treatment of $C x$. quinquefasciatus with different plant extracts, such as, the leaves of Atlantia monophylla. (Sivagnaname and Kalyanasundaram 2004), Ageratina adenophora (Raj Mohan and Ramaswamy 2007) and the bark essential oil of (Cinnamon) Cinnamomum osmophloeum, the leaf essential oil of (Chamomell) Matrichria chamomella (El-Dakhil, 2011) and black seed and sesame oils (Khater, 2003).

In conclusion, the use of natural products may be considered as an important alternative insecticide for control of mosquito larvae. The result from these study demonstrated that the cinnamon essential oil have excellent mosquito larvicidal activity and emergence inhibition against the mosquito $C x$. quinquefasciatus.

\section{REFERENCES}

Abbott, W. S., (1925) A method of computing the effectiveness of an insecticide. J. Econ. Ent. 18: (265267).

Abou El-Ela, Helmy, N.M., El- Monairy, O.M. and Salah, H. (1995). Effect of certain plant extracts on some biochemical aspects of the house fly larvae Musca domestica (Diptera:Moluscidae).Bull. Ent. Soc. Egypt. Econ.22:17-25.

Al-Mehmadi, R.M. and Al-Khalaf, A.A. (2010). Larvicidal and histological effects of Melia azedarach extract on Culex quinquefasciatus Say larvae (Diptera: Culicidae). J. of King Saud Univ.. 22, PP. 77-85.

Al- Sharook, Z., Balan,K., Jiang, Y. and Rembold, H.(1991).Insect growth inhibitors from tropical Meliaceae effect of crude extracts on mosquito larvae. J.appl.Entomol., III: 425-430.
Ahmed, A. M. (2004). A dual effect for the black seed oil on the Malaria vector Anopheles gambiae: Enhances immunity and reduces the concomitant reproductive cost. J. of Entomol. 4 (1): 1-19.

Brown, A.W.A. (1986). Insecticide resistance in mosquitoes: pragmatic review. J. Am. Mosq. Control Assoc. 2, PP. 123-140.

Chaithong, U.; Choochote, W.; Kamsuk, K.; Jitpakdi, A.; Tippawangkosol, P.; Chaiyasit, D.; Champakaew, D.; Tuetun, B. and Pitasawat, B. (2006). Larvicidal effect of pepper plants on Aedes aegypti (L) (Diptera: Culicidae). J. Vector Ecol. 31, PP. 138-143.

Chang, S.T., Chen, P.F., Chang,S.C., (2001).Antibacterial activity of leaf essential oils and their constituents from Cinnamomum osmophloeum. J. Ethnopharmacol. 77, 123-127.

Chang,S.T., Cheng,S.S., (2002). Antitermitic activity of leaf essential oils and components from Cinnamomum osmophloeum J. Agric. food Chem.50, 1389 -1392.

Chao, L.K., Hua, K.F., Hsu, H.Y., Cheng, S.S., Liu, J.Y., Chang, S.T., (2005). Study on the anti- inflammatory activity of essential oil from leaves of Cinnamomum osmophloeum. J. Agric. food Chem.53, 7274-7278.

Chao, L.K., Hua, K.F., Hsu, H.Y., Cheng, S.S., Liu, J.Y. Tsai, K.H., Chen W.J., Chang, S.T., (2008). Cinnamaldehyde inhibits pro-inflam matory cytokines secretion from monocytes/ macrophages through suppression of intracellular signaling. Food Chem.Toxicol.46, 220-231.

Cheng, S.S., Liu, J.Y. Tsai, K.H., Chen W.J., Chang, S.T. (2004). Chemical composition and mosquito larvicidal activity of essential oils from leaves of different Cinnamomum osmophloeum provenances. J. Agric. Food Chem.52, 4395 -4400.

Cheng, S.S., Liu, J.Y. Hsui, Y.R., Chang, S.T. (2006). Chemical polymorphism and antifungal activity of essential oils from leaves of different provenances of indigenous cinnamon (Cinnamomum osmophloeum) .Bioresour .Technol.97,306-312.

Cheng, S-S.; Liu, J-Y.; Huang, C-G.; Hsui, Y-R.; Chen, W-J. and Chang, S-T. (2008). Insecticidal activities of leaf essential oils from Cinnamomum osmophloeum against three mosquito species. J.Bioresource Technology. 100 (1), PP. 457-464.

El-Dakhil A.A. (2011) .Laboratory evaluation of some essential oils against immature stages of the filarial mosquito Culex quinquefasciatus (Culicidae: Diptera). M.sc. thesis. Taibah University, K.S.A.

El Hag , E. A., El Nadi, A.H., Zaitoon, A.A., (1999).Toxic and growth retarding effects of three plant extracts on Culex pipiens larvae (Diptera: Culicidae) Phytother. Res. 13, 388-392.

Finney, D. J. (1971). Propit analysis. Cambridge university Press, Cambridge. pp.318.

Forget. O. (1989). Pesticides, necessary but dangerous poisons. The IDRC Reports, 18:7-13. Gopalkrishna B, Patil SH. 
Insun, D.; Choochote, W.; Jitpakdi, A.; Chaithong, U.; Tippawangkosol, P. and Pitasawat, B. (1999). Possible site of action of Kaempferia galanga in killing Culex quinquefasciatus larvae. Southeast Asian J. Trop. Med. Publ. Hlth. 30: PP. 195-199.

Jayaprakasha G.K, Sigh R P, Pereira J, Sakariah K.K. (1997). Limonoids from Citrus reticulate and their moult inhibition activity in mosquito Culex quinquefasciatus larvae. Phytochem.44: 843-846.

Khater, H.F. Biocontrol of some insects .(2003) (Ph. D thesis- Fac.Vet.Med., Moshtohor, Zagazig univ. Benha Branch).

Lee, H.C., Cheng, S.S., Cheng, S.T. (2005). Antifungal property the essential oils and their constituents from cinnamomum osmophloeum leaf against three pathogenic fungi. J.Sci.85, 2047 -2053.

Muthukrishnan, J. and Puspalatha, E. (2001). Effects of plant extracts on fecundity and fertility of mosquitoes. J. Appl. Entomol. 125, PP. 31-35.
Mohsen, Z.H., Jawad, A.L.M., Al- Chalabi, B.M.\& Al- Naib, A.(1990). Biological activity of Callistemon lanceolatus against Culex quinquefasciatus. Fitoterapia, 61:270-274.

Raj Mohan, D. and Ramaswamy, M. (2007). Evaluation of larvicidal activity of the leaf extract of a weed plant, Ageratina adenophora, against two important species of mosquitoes, Aedes aegypti and Culex quinquefasciatus. Afr. J. Biotechnol. 6(5), PP: 631-638.

Saleh, E.H. (1995).Effect of some botanical extracts as potential insecticides for the control of some mosquitoes in Egypt.(Ph.D. thesis -Dep. Entomol. Fac. Sci. Cairo Univ., Egypt).

Sharma, P.; Mohan, L. and Srivastava, C.N. (2009). Antijuvenile activity of Azadirachta indica extract on the development and morphometry of filaria vector, Culex quinquefasciatus (Diptera: Culicidae) Say. Parasitol. Res. 105(5), PP. 1193-1203.

Steel, R.G. and J.H.Torrie (1980).Principles and procedures of statistics. Abiometrical approach, ${ }^{2 n d}$ ed. Mc .GrawHill Book Co., New York.

World Health Organization (1981). Instructions for determining the susceptibility or resistance of mosquito larvae to insecticides. WHO/VBC., 81:807. 


\section{الملخص العربي}

\section{التقييم المعملي لبعض الزيوت النباتية ضد الأطوار غير الكاملة لبعوضة \\ Culex quinquefasciatus (Diptera: Culicidae)}

عبير عبد المجيد جاد

$$
\begin{aligned}
& \text { القرفـة بتركيز 65065 جـزء في المليـون الي تثبـيط خـروج الحشـرات } \\
& \text { الكاملة من طور العذراء بنسبة 100\%. } \\
& \text { تم دراسـة النشـاط السـمي لأربعة زيـوت نباتيـة هي (زيـت حبـة }
\end{aligned}
$$

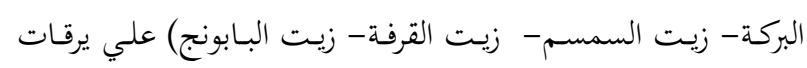

$$
\begin{aligned}
& \text { كما ادت المعاملة بالزيوت موضع الدراسة الي الخفاض في اعداد } \\
& \text { العمر الرابع من بعوضة الكيولكس وقد اظهرت النتائج ان قيمة التركيز }
\end{aligned}
$$

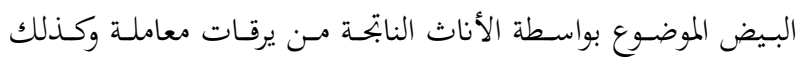

$$
\begin{aligned}
& \text { القاتل ل50\% مـن اليرقات 82، 26، 32، } 26 \text { جـزء في المليون) }
\end{aligned}
$$

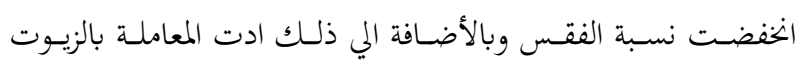

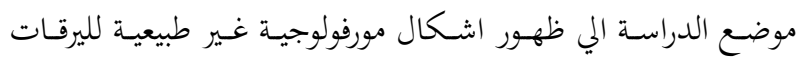

$$
\begin{aligned}
& \text { والعذاري. } \\
& \text { وقد انتهت الدراسة الي ان زيت القرفة كان اكثر الزيوت موضع }
\end{aligned}
$$

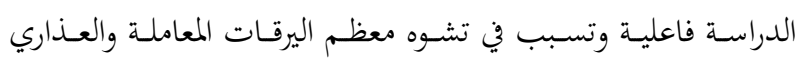

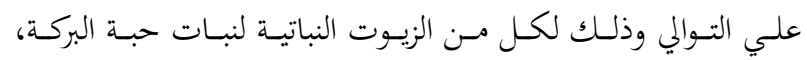

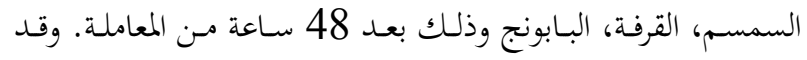

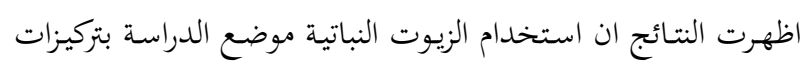

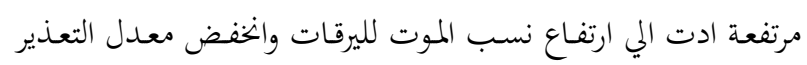

$$
\begin{aligned}
& \text { ومعدل خروج الحشرات الكاملة من العذراء. }
\end{aligned}
$$

